\title{
Impact of Water Deficit on Nutritional Quality of Tomatoes
}

\author{
Galina Pevicharova, Daniela Ganeva and Stanislava Grozeva
}

\begin{abstract}
The answer of promising tomato genotypes to the water stress on some basic chemical compounds related to the biological value and sensory quality of the fruits was evaluated. Ten Bulgarian tomato genotypes were on the focus. They had been determined as tolerant to drought in a large Bulgarian collection after two-year experiment. The applied reduced irrigation led to an improvement of the nutritional quality of the tomato fruits. All studied genotypes reacted with an increase of the total soluble solids and ascorbic acid contents in reduced irrigation. A genotype reaction toward water deficit was better expressed in contents of lycopene and titratable organic acids.
\end{abstract}

Keywords - Ascorbic acid, lycopene, reduced irrigation, Solanum licopersicum L. $_{\text {, total soluble solids }}$

\section{INTRODUCTION}

Tomatoes are a natural source of healthy components for the human body. Consumption of fresh tomatoes and tomato products leads to prevention of chronic diseases such as cancer and cardiovascular disease due to the high level of lycopene, beta-carotene and ascorbic acid [1], [2]. The biosynthesis of these three components with antioxidant effect is influenced by environmental conditions during the plant growth [3]. Water deficit and poor water quality are the main factors affecting yield and tomato quality in terms of nutritional value and food [4], [5].

As a result of climate changes and their effect on water resources many studies in the last years have been dedicated to tomato growth under reduced irrigation. Generally, it was established that under certain degree of water deficit the biological value of the fruits were improved while the yield was reduced [6]-[8]. According to [9], [10] there was a significant increase in lycopene content during water stress. In contrast, [11] reported about the decrease of the lycopene content in reduced irrigation compared to well-watered plants. The results were in accordance with the statement of [12] that under soil water deficit conditions the carotenoid biosynthetic

Galina Todorova Pevicharova, Maritsa Vegetable Crops Research Institute, Plovdiv, Bulgaria

Daniela Ganeva Ganeva, Maritsa Vegetable Crops Research Institute, Plovdiv, Bulgaria,

Stanislava Yordanova Grozeva, Maritsa Vegetable Crops Research Institute, Plovdiv, Bulgaria pathway is more ' $\beta$-carotene accumulation' oriented especially at the beginning of the fruit ripening process.

The influence of the irrigation regime on the ascorbic acid synthesis in tomato fruits was recorded as relatively minor [13] or of great degree [14]. Significant increases in total soluble solids of tomato fruits were observed under drought [15], [16]. There were reports of tomato fruit acidity enhance under water deficits [7], [17].

Summer in Bulgaria is often warm and dry. The scientific works on many years of changes in precipitation showed a decreasing trend of rainfall amounts in many regions of the country [18]. In this respect, the efforts of tomato team at Maritsa Institute have been oriented towards development of drought tolerant tomato varieties suitable for growing under elevated temperatures.

The purpose of the present study was to evaluate the answer of promising tomato genotypes to the water stress on some basic chemical compounds related to the biological value and sensory quality of the fruits.

\section{MATERIALS AND METHODS}

Field design: The experiment was carried out during 20172018 period at the Maritsa Vegetable Crops Research Institute in Plovdiv, Bulgaria. The sowing of the tomato genotypes was done at the beginning of April in an unheated greenhouse. The seedlings were transplanted into an open field at the beginning of May. Ten plants of each genotype on an area of $2.4 \mathrm{~m}^{2}$ in two replications were grown. Optimum (well-watered) and $50 \%$ reduced watering regimes were applied using a drip irrigation system. The reduced irrigation was applied 20 days after transplanting when the plants were well adapted to the field. During the crop period standard agronomic practices such as fertilization and plant protection were utilized.

Plant material: Ten Bulgarian tomato genotypes were evaluated. They were determined as tolerant to drought in a large Bulgarian collection after two year experiment [19]-[21]. Two indeterminate genotypes of cherry type (BG Alia and BG 1923) and one of domesticated type (BG 617) were included. The genotypes of determinate growth form were presented by one of cherry type (BG 1620) and six of tomato type for processing (BG Marti, BG 2081, BG 895, BG 11, BG $10 \beta$ and BG K3). The fruits of all genotypes were of red colour except BG $10 \beta$ with orange one.

Chemical analyses: Analysis of the chemical compounds of the fruits was performed at the Laboratory for Vegetable 
Quality Control of Maritsa Institute. Samples of 20 mature fruits were assessed on the followed fruit quality parameters: total soluble solids (TSS) using a digital refractometer; titratable acid content calculated as citric acid after titration with $0.1 \mathrm{~N} \mathrm{NaOH}$; ascorbic acid by Tilman's reaction with 2,6-dichlorophenolindophenol [22]; lycopene by [23].

Climate parameters: Weather data were collected for both tomato crops from June to August in 2017 and 2018 by weather station Caipos Wave (Caipos $\mathrm{GmbH}$, Austria). Air temperature minimum and maximum $\left({ }^{\circ} \mathrm{C}\right)$, air humidity $(\%)$, rainfalls $\left(1 / \mathrm{m}^{2}\right)$ and soil moisture at 15 and $30 \mathrm{~cm}$ depth $(\mathrm{kPa})$ were recorded.

Data analysis: A two-way analysis of variance was applied to evaluate the effect of genotype, water regime and their interaction on the studied traits. The percentage of increase $\left(\mathrm{I}_{\%}\right)$ was calculated. Significant differences in the increase of the chemical compounds were determined by Duncan's multiple range test $(\mathrm{p}<0.05)$. Correlation coefficients were also calculated. All data analyses were performed using SPSS-16 software.

\section{RESUlTS AND Discussion}

In 2017 the climatic conditions in Plovdiv were appropriate for the goal of the study. Temperatures over $33^{\circ} \mathrm{C}$ were recorded in $62 \%$ of the days in the period of 12 June to 31 August with peaks over $40^{\circ} \mathrm{C}$ in the last decade of June and the second decade of July (Figure 1). The total rainfalls were 76,5 $1 / \mathrm{m}^{2}$.

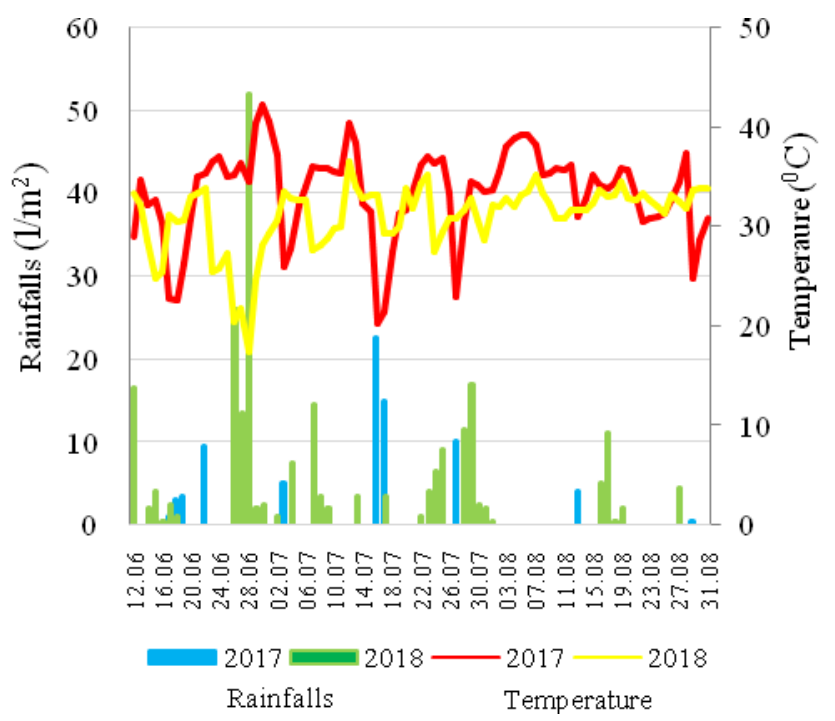

Fig.1. Maximum daily temperatures and rainfalls during the experimental period

The summer in 2018 was hot but not so dry compared to the summer of 2017. Temperatures over $33^{\circ} \mathrm{C}$ were recorded in $30 \%$ of the days of the experimental period. The total rainfalls were more than the previous year i.e $2561 / \mathrm{m}^{2}$.

Water scarcity affected the contents of the total soluble solids. All studied genotypes reacted with an increase of this trait (Figure 2). The highest increase was recorded in three determinate genotypes for processing BG 11 , BG $10 \beta$ and BG K3. Cherry genotypes BG Alia, BG 1923 and BG 1620 which possessed the highest content of the total soluble solids in the fruits grown in optimum irrigation showed the weakest change under drought conditions. The results were similar to those obtained by [24] who explained that the increases were related primary to the decreases of fruit water content and to slight increase in soluble sugars. In contrast, according to [25] the reduced irrigation did not have any effect on the total soluble solids.

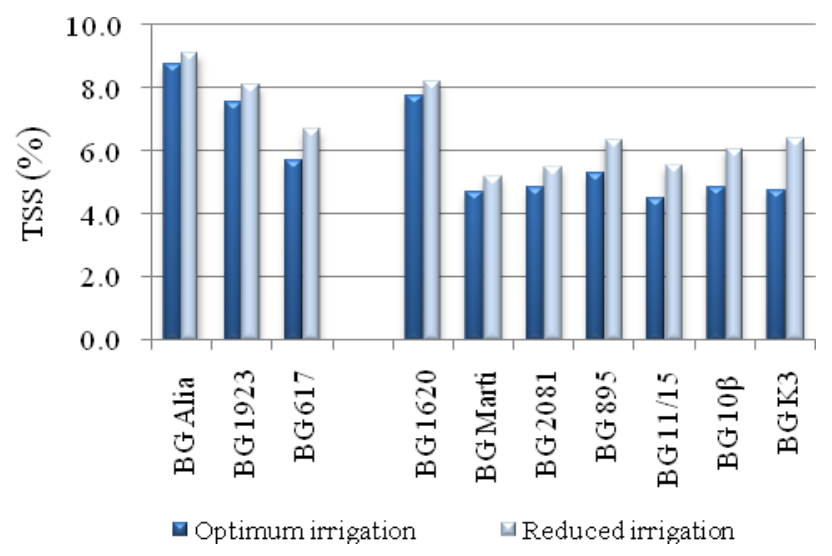

Fig.2. Total soluble solids of tomato fruits from optimum irrigated and reduced irrigated plants

All tomato genotypes synthesized more ascorbic acid in water deficit (Figure 3). The weakest change was observed in orange-colored genotype BG $10 \beta$. The greatest increase was record in determinate genotypes BG Marti and BG K3.

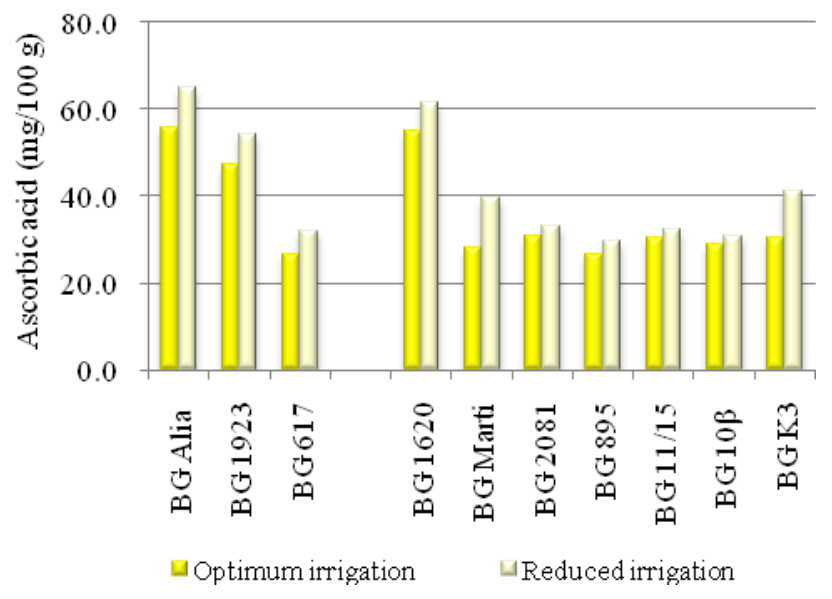

Fig.3. Ascorbic acid content of tomato fruits from optimum irrigated and reduced irrigated plants

Analogous results were reported by [7], [14]. The results were in contrast with those obtained by [25] who stated that immediate moisture stress reduced the vitamin $C$ content of fruits. As a probable cause they showed the increased leaf temperature.

The percentages of increase were positive for both total soluble solids and ascorbic acid contents (Table 1). 
TABLE I

INCREASE IN THE VALUES OF THE STUDIED CHEMICAL COMPONENTS IN TOMATOES GROWN UNDER REDUCED IRRIGATION

\begin{tabular}{|c|c|c|c|c|}
\hline \multirow[b]{2}{*}{ Genotypes } & \multicolumn{4}{|c|}{ Increase of the values $\left(I_{\%}\right)$} \\
\hline & TSS & $\begin{array}{c}\text { Titratable } \\
\text { organic } \\
\text { acids }\end{array}$ & $\begin{array}{l}\text { Ascorbic } \\
\text { acid }\end{array}$ & Lycopene \\
\hline \multicolumn{5}{|c|}{ Indeterminate genotypes } \\
\hline BG Alia & $6.60^{\mathrm{b}}$ & $9.09^{\mathrm{bc}}$ & $21.00^{\mathrm{ab}}$ & $-5.62^{\mathrm{de}}$ \\
\hline BG 1923 & $8.98^{\mathrm{b}}$ & $27.23^{\mathrm{a}}$ & $16.60^{\mathrm{ab}}$ & $7.83^{\text {abcde }}$ \\
\hline BG 617 & $17.88^{\mathrm{ab}}$ & $10.99^{\mathrm{bc}}$ & $20.10^{\mathrm{ab}}$ & $16.71^{\mathrm{abc}}$ \\
\hline \multicolumn{5}{|c|}{ Determinate genotypes } \\
\hline BG 1620 & $7.97^{\mathrm{b}}$ & $-12.28^{\mathrm{d}}$ & $14.22^{\mathrm{ab}}$ & $21.90^{\mathrm{ab}}$ \\
\hline BG Marti & $10.57^{\mathrm{b}}$ & $4.71^{\mathrm{bc}}$ & $42.57^{\mathrm{a}}$ & $0.82^{\text {bcde }}$ \\
\hline BG 2081 & $13.39^{\mathrm{b}}$ & $18.89^{\mathrm{ab}}$ & $9.81^{\mathrm{b}}$ & $14.23^{\mathrm{abcd}}$ \\
\hline BG 895 & $20.27^{\mathrm{ab}}$ & $18.21^{\mathrm{ab}}$ & $17.78^{\mathrm{ab}}$ & $-7.32^{\mathrm{d}}$ \\
\hline BG 11 & $25.61^{\mathrm{ab}}$ & $18.93^{\mathrm{ab}}$ & $9.32^{\mathrm{b}}$ & $8.91^{\text {abcde }}$ \\
\hline BG $10 \beta$ & $26.21^{\mathrm{ab}}$ & $-0.88^{\mathrm{cd}}$ & $8.91^{\mathrm{b}}$ & $0.48^{\text {cde }}$ \\
\hline BG K3 & $39.53^{\mathrm{a}}$ & $12.51^{\mathrm{abc}}$ & $39.58^{\mathrm{a}}$ & $28.41^{\mathrm{a}}$ \\
\hline
\end{tabular}

$\mathrm{a}, \mathrm{b}, \mathrm{c} \ldots$ - Duncan's multiple range test $(\mathrm{p}<0.05)$

The fruits of most genotypes were richer of titratabe organic acids in reduced irrigation (Figure 4). Only BG 1620 decreased the content of the investigated component by $12.28 \%$ (Table 1). Genotype BG $10 \beta$ kept almost the same values regardless of the applied watering regime.

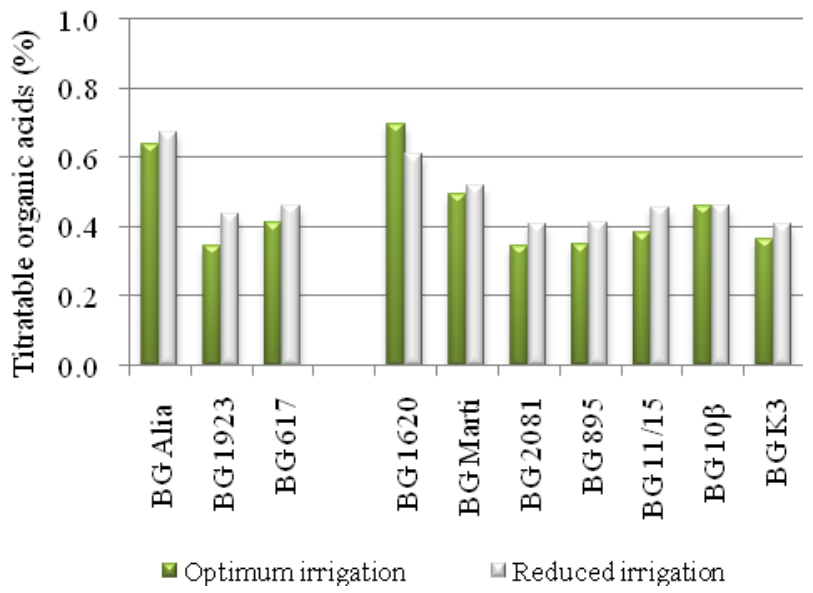

Fig.4. Titratable organic acids of tomato fruits from optimum irrigated and reduced irrigated plants

The lycopene content in tomato fruits was higher in four of the investigated genotypes in water deficit (Figure 5). BG Alia and BG 895 distinguished by a decrease of the lycopene. Negative values for $I_{\%}$ were calculated for them (Table 1). Genotypes BG Marti and BG $10 \beta$ did not change the values in both watering regimes. An increase in lycopene content was also found by [8], [10] in tomatoes grown in reduced irrigation. Conversely, lower lycopene content was recorded under conditions of water scarcity by [11].

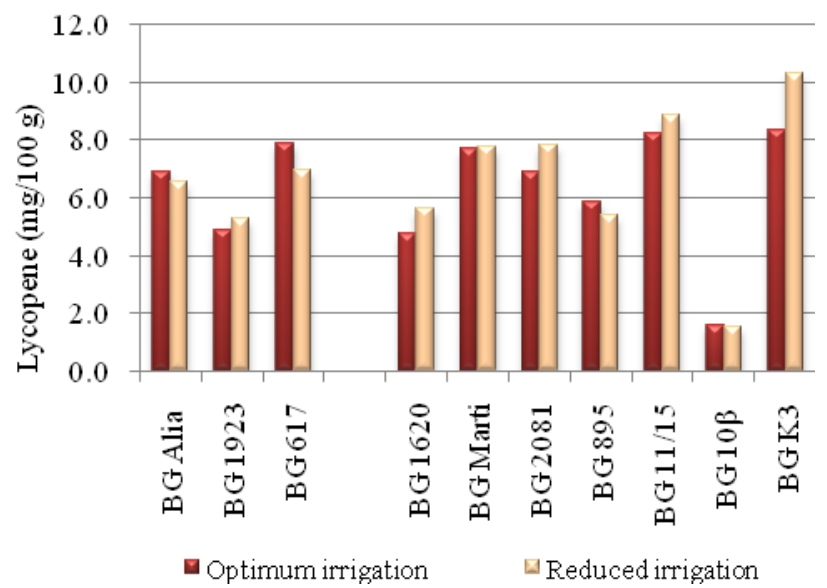

Fig.5. Lycopene content of tomato fruits from optimum irrigated and reduced irrigated plants

Two-way analysis of variance showed a stronger influence of the genotype than the level of the irrigation supply on the four analyzed chemical compounds in tomato fruits (Table 2). It was probably due to the diversity of the investigated genotypes ranging from cherry to large-fruited tomatoes.

TABLE II

TWO-WAY ANALYSIS OF VARIANCE

\begin{tabular}{|l|c|c|c|c|}
\hline \multirow{2}{*}{$\begin{array}{c}\text { Chemical } \\
\text { components }\end{array}$} & $\begin{array}{c}\text { Genotype } \\
\text { (A) }\end{array}$ & $\begin{array}{c}\text { Water } \\
\text { regime } \\
\text { (B) }\end{array}$ & A x B & Residue \\
\cline { 2 - 5 } TSS & $78.61 * * *$ & $7.70 * * *$ & 1.65 & 12.04 \\
\hline $\begin{array}{l}\text { Titratable } \\
\text { organic acids }\end{array}$ & $71.74 * * *$ & 2.20 & 3.83 & 22.24 \\
\hline Ascorbic acid & $76.36 * * *$ & $4.73 *$ & 1.65 & 17.26 \\
\hline Lycopene & $85.20 * * *$ & 1.27 & 2.33 & 11.20 \\
\hline
\end{tabular}

Nevertheless, significant influence of the water regime was registered for the total soluble solids and ascorbic acid contents. These components seem to be more drought sensitive than the titratable organic acids and lycopene in tomato fruits.

The high values of the correlation coefficients between the data of well-watered plats and the data of water stressed-plants $(\mathrm{r}=0.758 * *$ for soluble solids; $\mathrm{r}=0.891 * *$ for ascorbic acid; $\mathrm{r}$ $=0.917^{* *}$ for titratable organic acids; $r=0.920 * *$ for lycopene) confirmed the genotype response to water stress. A genotype reaction toward water deficit was better expressed in lycopene content. These results agreed with the findings of [26] who declared that the effects on content of antioxidants were cultivar-dependent. The similar trend was also found by [13].

Concerning the investigated compounds in the present experiment, the answer of BG K3 to water stress was the most expressed. As TSS and acids contents are responsible for the 
tomato taste, it could be assumed that the deficit irrigation treatment has affected BG Alia and BG Marti sensory profile to the slightest degree. The biological value determined by ascorbic acid and lycopene was more stable in the fruits of BG 2081, BG 11 and BG $10 \beta$.

\section{CONCLUSION}

The applied regime of water deficit combined with the elevated summer temperatures in Bulgaria for the period of tomato growth during our investigation caused both positive and negative changes in the studied fruit compounds of the investigated tomato genotypes. Reduced irrigation benefited nutritional quality of most of them. The assessment of the nutrient quality will give added information about the biological profile of the investigated tomato accessions and will help breeders to find the right parental components for successful breeding of drought tolerant tomato varieties.

\section{ACKNOWLEDGMENT}

This study is part of the TomGEM project that has received funding from the European Union's Horizon 2020 research and innovation programme under grant agreement No 679796.

\section{REFERENCES}

[1] S. Agarwal, and A. Rao, "Tomato lycopene and its role in human health and chronic diseases", Canadian Medical Association Journal, Vol.163, no. 6, pp. 739-44, 2000. www.ncbi.nlm.nih.gov/pmc/articles/PMC80172

[2] R. Borguinia, and E. Da Silva Torre, "Tomatoes and tomato products as dietary sources of antioxidants", Food Reviews International, vol. 25, no.4, pp. 313-325, Apr. 2009. https://doi.org/10.1080/87559120903155859

[3] Y. Dumas, M. Dadomo, G. Di Lucca, and P. Grolier, "Effects of environmental factors and agricultural techniques on antioxidant content of tomatoes", Journal of the Science of Food and Agriculture, vol. 83, no.5, pp. 369-382, 2003. https://doi.org/10.1002/jsfa.1370

[4] M. Dorais, D. Ehret, and A. Papadopoulos, "Tomato (Solanum lycopersicum) health components: from the seed to the consumer", Phytochemistry Reviews, vol.7, pp. 231-250, 2008. https://doi.org/10.1007/s11101-007-9085-X

[5] R. Agbemafe, J. Owusu-Sekyere, and A. Bart-Plange, "Effect of deficit irrigation and storage on the nutritional composition of tomato (Lycopersicon esculentum Mill. cv. Pectomech), Croatian Journal of Food Technology, Biotechnology and Nutrition, vol. 10, no.1-2, pp. 5965, 2015. https://hrcak.srce.hr/147824

[6] U. Veit-Köhler, A. Krumbein, and H. Kosegarten, "Effect of different water supply on plant growth and fruit quality of Lycopersicon esculentum", Journal of Plant Nutrition and Soil Science, vol. 162, pp. 583-588, 1999.

https://doi.org/10.1002/(SICI)1522-2624(199912)162:6<583::AIDJPLN583>3.0.CO;2-P

[7] L. Mingchi, L. Xiangli, H. Jing, and G. Lihong, "Effect of simulated drought stress on plant growth, yield and fruit properties of tomato", Acta Horticulturae, vol. 856, pp. 193-202, 2010. https://doi.org/10.17660/ActaHortic.2010.856.26

[8] F. Favati, S. Lovelli, F. Galgano, V. Miccolis, T. Di Tommaso, and V. Candido, "Processing tomato quality as affected by irrigation scheduling", Scientia Horticulturae, vol. 122, pp. 562-571, 2009. https://doi.org/10.1016/j.scienta.2009.06.026
[9] A. Giannakoula, and I. Ilias, "The effect of water stress and salinity on growth and physiology of tomato (Lycopersicon esculentum Mill). Archives of Biological Sciences, vol. 65, no. 2, pp. 611-620, 2013. https://doi.org/10.2298/ABS1302611G

[10] D. Nangare, Y. Singh, P. Kumar, P. Minhas, "Growth, fruit yield and quality of tomato (Lycopersicon esculentum Mill.) as affected by deficit irrigation regulated on phenological basis", Agricultural Water Management, vol. 171, pp. 73-79, 2016. https://doi.org/10.1016/j.agwat.2016.03.016

[11] N. Atkinson, T. Dew, C. Orfila, and P. Urwin, "Influence of combined biotic and abiotic stress on nutritional quality parameters in tomato (Solanum lycopersicum L.)", Journal of Agricultural and Food Chemistry, vol. 59, pp. 9673-9682, 2011. https://doi.org/10.1021/jf202081t

[12] E. Riggi, C. Patané, and G. Ruberto, "Content of carotenoids at different ripening stages in processing tomato in relation to soil water availability", Australian Journal of Agricultural Research, vol. 59, no. 4, pp. 348-353, 2008. https://doi.org/10.1071/AR07215

[13] G. Pevicharova, D. Ganeva, D. Zamir, "Effect of irrigation on ascorbic acid content of Solanum cheesmaniae tomato collection", Plant Science , vol. 50, pp. 70-74, 2013. (Певичарова, Г., Ганева, Д., Замир, Д. 2013. "Влияние на напояването върху съдържанието на аскорбинова киселина в колекция домати Solanum cheesmaniae”, Растениевъдни науки 50: 70-74).

[14] K, Nahar, and R. Gretzmacher, "Effect of water stress on nutrient uptake, yield and quality of tomato (Lycopersicon esculentum Mill.) under subtropical conditions", Die Bodenkultur, vol. 53, pp. 45-51, 2002.Available http://citeseerx.ist.psu.edu/viewdoc/download?doi=10.1.1.628.6828\&re $\mathrm{p}=$ rep1\&type $=$ pdf

[15] S. De Pascale, A. Martino, G. Raimondi, and A. Maggio, "Comparative analysis of water and salt stress-induced modifications of quality parameters in cherry tomatoes", The Journal of Horticultural Science and Biotechnology, vol. 82, no. 2, pp. 283-289, 2007. https://doi.org/10.1080/14620316.2007.11512230

[16] R. Sivakumar, and S. Srividhya, "Impact of drought on flowering, yield and quality parameters in diverse genotypes of tomato (Solanum lycopersicum L.)", Advances in Horticultural Science, vol. 30, no. 1. pp. 3-11, 2016.

http://dx.doi.org/10.13128/ahs-18696

[17] J. Rudich, D. Kalmar, G. Giezenberg, and S. Harel, "Low water tensions in defined growth stages of processing tomato plants and their effects on yield and quality", Journal of Horticultural Science, vol. 52, pp. 391-399, 1977.

https://doi.org/10.1080/00221589.1977.11514768

[18] B. Vekilska, and G. Rathcev, "Current Changes in the Precipitation in Bulgaria" Sofia University Year Book-Geography, vol. 90, pp. 31-37, 2000.

[19] D. Ganeva, St. Grozeva, and G. Pevicharova, "Evaluation of productivity and productivity compounds in tomato accessions grown under elevated temperature and reduced irrigation", Agriculture \& Food, vol. 6, pp. 99-110, 2018.

Available at: https://www.scientificpublications.net/get/1000028/1532006366348943.pdf

[20] St. Grozeva, D. Ganeva, and G. Pevicharova, "Influence of reduced irrigation on phenological and morphological characters of different tomato genotypes", Agriculture \& Food, vol. 6, pp. 111-121, 2018. Available at: https://www.scientificpublications.net/get/1000028/1532006407953187.pdf

[21] G. Pevicharova, D. Ganeva, and St. Grozeva, "Impact of water deficit on sensory profile of tomato (Solanum lycopersicon L.) grown under hot summer conditions in Bulgaria", Agriculture \& Food, vol. 6, pp. 122137, 2018.

Available at: https://www.scientificpublications.net/get/1000028/1532006459684415.pdf

[22] A. Genadiev, D. Kalcheva, N. Nenchev, N. Tevekeliev, N. Chavdarova, Food Analyses, Technique, Sofia, 1969, 695 pp. 
[23] H. Manuelyan, "Express methods for assessing the carotenoid composition of tomato fruits", in Genetic Improvement of Tomato, G. Kallo, Ed. Spring -Velag, 1991, pp. 193-195.

[24] J. Mitchell, C. Shenna, S. Grattan, and D. May, "Tomato fruit yields and quality under water deficit and salinity", Journal of the American Society for Horticultural Science, vol. 116, no. 2, pp. 215-221, 1991. https://doi.org/10.21273/JASHS.116.2.215

[25] R.Vijitha, S. Mahendran, "Effect of moisture stress at different growth stages of tomato plant (Lycopersicon esculentum Mill.) on yield and quality of fruits “, Journal of Science of the University of Kelaniya, vol. 5, pp. 1-11, 2010. http://dx.doi.org/10.4038/josuk.v5i0.4086

[26] A. Bogale, M. Nagle, S. Latif, M. Aguila,and J. Müller, 2016, "Regulated deficit irrigation and partial root-zone drying irrigation impact bioactive compounds and antioxidant activity in two select tomato cultivars". Scientia Horticulturae, vol. 213, pp. 115-124.

https://doi.org/10.1016/j.scienta.2016.10.029 